\title{
Guadinomines, Type III Secretion System Inhibitors, Produced by Streptomyces sp. K01-0509
}

\author{
I. Taxonomy, Fermentation, Isolation and Biological Properties \\ Masato Iwatsuki, Ryuji Uchida, Hitomi Yoshijima, Hideaki Ui, Kazuro Shiomi, \\ Atsuko Matsumoto, Yoko Takahashi, Akio Abe, Hiroshi Tomoda, Satoshi Ōmura
}

Dedicated to the late Prof. Shigeo Iwasaki

Received: January 22, 2008 / Accepted: April 4, 2008

(C) Japan Antibiotics Research Association

\begin{abstract}
Enteropathogenic Escherichia coli (EPEC) expressing the Type III secretion system (TTSS) induced hemolysis of sheep blood cells. Using this assay, six structurally related compounds designated as guadinomines were isolated as inhibitors of TTSS-induced hemolysis by ion exchange column chromatography and HPLC from the culture broth of Streptomyces sp. K01-0509. Guadinomines $\mathrm{A}$ and $\mathrm{B}$ showed potent inhibition with $\mathrm{IC}_{50}$ values of 0.02 and $0.007 \mu \mathrm{g} / \mathrm{ml}$, respectively, guadinomine $\mathrm{D}$ showed moderate activity $\left(\mathrm{IC}_{50}: 8.5 \mu \mathrm{g} / \mathrm{ml}\right)$, while guadinomines $\mathrm{C}_{1}$ and $\mathrm{C}_{2}$ and guadinomic acid had no activity.
\end{abstract}

Keywords guadinomines, Type III secretion system (TTSS)-induced hemolysis, Streptomyces sp. K01-0509, EPEC

\section{Introduction}

Our research group has focused on the discovery of antiinfectives from microbial metabolites [1 3]. The Type III secretion system (TTSS) is a common virulence system present in many Gram-negative bacteria, including Yersinia spp., Salmonella spp., Shigella spp., Pseudomonas aeruginosa, EPEC, enterohemorragic E. coli (EHEC), and
Chlamydia spp. [4]. These bacteria use TTSS to deliver effector proteins into the cytosol of the eukaryotic target cell and depend on their respective TTSS to invade the host, resist phagocytosis, grow in deep tissues, and cause disease [5]. Recent studies have revealed that TTSS is not essential for the survival of bacteria and is not found in non-pathogenic Gram-negative bacteria except for some kinds of symbiotic bacteria.

Based on the new concept of "anti-infective drugs" developed by Ōmura [6], we have focused on TTSS as a new target for anti-infective drugs. Namely, a specific inhibitor of TTSS is expected to attenuate pathogens specifically and inhibit the process of their infection without killing pathogens and affecting normal bacterial flora. And such a specific agent would be expected to target the system only involved in the virulence mechanism. Thus, there would be little or no selective pressure for viability, potentially reducing the development of resistance. A convenient assay system in screening for TTSS inhibitors from microbial metabolites was employed using TTSS-induced hemolysis [7]. As a part of this screening program, we discovered six novel compounds designated guadinomines A to D and guadinomic acid (Fig. 1), produced by actinomycete strain K01-0509. The structure elucidation of these guadinomines will be
M. Iwatsuki, R. Uchida ${ }^{\dagger}$ A. Matsumoto, S. Ōmura (Corresponding author): The Kitasato Institute, 5-9-1 Shirokane, Minato-ku, Tokyo 108-8642, Japan,

E-mail: omura-s@kitasato.or.jp

H. Ui, K. Shiomi, H. Yoshijima, Y. Takahashi, A. Abe, H. Tomoda $^{\dagger}$ (Corresponding author), S. Ōmura: Kitasato Institute for Life Sciences and Graduate School of Infection Control Sciences, Kitasato University, 5-9-1 Shirokane, Minato-ku, Tokyo 108-8641, Japan, E-mail: tomodah@pharm.kitasato-u.ac.jp

${ }^{\dagger}$ Present address: School of Pharmacy, Kitasato University, 5-9-1 Shirokane, Minato-ku, Tokyo 108-8641, Japan 


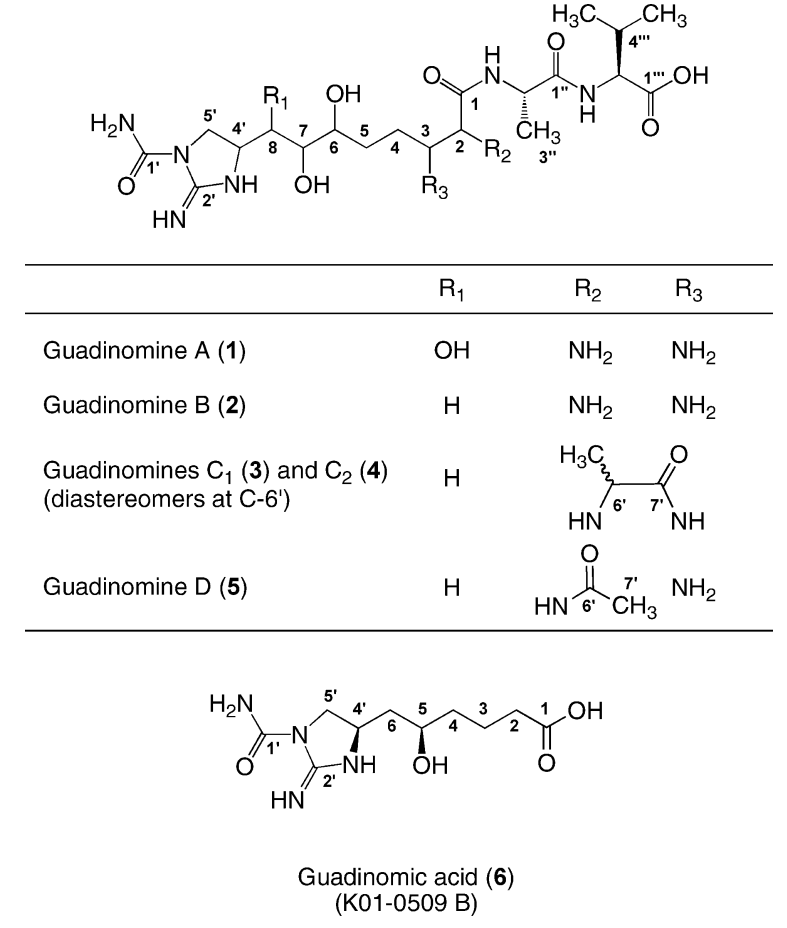

Fig. 1 Structures of guadinomines $A, B, C_{1}, C_{2}$ and $D$ and guadinomic acid.

published in an accompanying study [8]. In this study, the taxonomy, fermentation, isolation, and biological properties of guadinomines are described.

\section{Materials and Methods}

\section{Taxonomic Studies}

The International Streptomyces Project (ISP) media recommended by Shirling and Gottlieb [9] and media recommended by Waksman [10] were used to investigate the cultural and physiological characteristics. Cultures were routinely observed after incubation for two weeks at $27^{\circ} \mathrm{C}$. The utilization of carbon sources was tested by growth on Pridham and Gottlieb's medium containing 1.0\% carbon at $27^{\circ} \mathrm{C}$ [11]. Morphological properties were observed with a scanning electron microscope (model JSM-5600, JEOL). The type of diaminopimelic isomers present was determined by the method of Becker et al. [12]. Menaquinones were extracted and purified after Collins et al. [13], then analyzed by high performance liquid chromatography (HPLC) equipped with a CAPCELL PAK C18 column (Shiseido) [14].

\section{Fermentation}

Strain K01-0509 was grown and maintained on an agar slant consisting of $1.0 \%$ starch, $0.3 \% \mathrm{NZ}$ amine, $0.1 \%$ yeast extract, $0.1 \%$ meat extract, $1.2 \%$ agar and $0.3 \%$ $\mathrm{CaCO}_{3}$. A loopful of spores of Streptomyces sp. K01-0509 was inoculated into $100 \mathrm{ml}$ of the seed medium consisting of $2.4 \%$ starch, $0.1 \%$ glucose, $0.3 \%$ peptone, $0.3 \%$ meat extract, $0.5 \%$ yeast extract and $0.3 \% \mathrm{CaCO}_{3}$ (adjusted to pH 7.0 before sterilization) in a 500-ml Erlenmeyer flask. The inoculated flask was incubated in a rotary shaker ( $210 \mathrm{rpm}$ ) at $27^{\circ} \mathrm{C}$ for 3 days.

For production of guadinomines A, B and D, a 1-ml portion of the seed culture was transferred to a $500-\mathrm{ml}$ Erlenmeyer flask (total 49 flasks) containing $100 \mathrm{ml}$ of production Medium A (2.0\% galactose, $2.0 \%$ dextrin, $0.5 \%$ corn steep liquor, $1.0 \%$ Bacto-soytone, $0.2 \%\left(\mathrm{NH}_{4}\right)_{2} \mathrm{SO}_{4}$ and $0.2 \% \mathrm{CaCO}_{3}$ (adjusted to $\mathrm{pH} 7.4$ before sterilization)) and fermentation was carried out in a rotary shaker ( $210 \mathrm{rpm}$ ) at $27^{\circ} \mathrm{C}$ for 9 days.

For production of guadinomines $\mathrm{C}_{1}$ and $\mathrm{C}_{2}$, the seed culture $(200 \mathrm{ml})$ was transferred to a 30 -liter Jar fermentor (total of three fermentors) containing 20 liters of production Medium B (2.4\% starch, $0.1 \%$ glucose, $0.3 \%$ peptone, $0.3 \%$ meat extract, $0.5 \%$ yeast extract, $0.4 \% \quad \mathrm{CaCO}_{3}, \quad 5.0 \times 10^{-4} \% \quad \mathrm{FeSO}_{4} \cdot 7 \mathrm{H}_{2} \mathrm{O}, \quad 5.0 \times 10^{-4} \%$ $\mathrm{MgCl}_{2} \cdot 4 \mathrm{H}_{2} \mathrm{O}, 5.0 \times 10^{-4} \% \mathrm{CuSO}_{4} \cdot 5 \mathrm{H}_{2} \mathrm{O}$ and $5.0 \times 10^{-4} \%$ $\mathrm{CoCl}_{2} \cdot 6 \mathrm{H}_{2} \mathrm{O}$ (adjusted to $\mathrm{pH} 7.0$ before sterilization)) and fermentation was carried out at $27^{\circ} \mathrm{C}$ with an air flow of 10 liters/minute for 4 days.

For production of guadinomic acid, a 1-ml portion of the seed culture was transferred to a 500-ml Erlenmeyer flask (total 42 flasks) containing $100 \mathrm{ml}$ of production Medium B and fermentation was carried out in a rotary shaker (210 rpm) at $27^{\circ} \mathrm{C}$ for 6 days.

The time courses of inhibitory activity against TTSS by the supernatant of the culture broth $(0.5 \mu \mathrm{l})$, the $\mathrm{pH}$ of the culture and packed cell volume (PCV, $\mathrm{ml} / 10 \mathrm{ml})$ after centrifugation $(3,000 \mathrm{rpm}, 10$ minutes $)$ of the culture $(10 \mathrm{ml})$ during fermentation were measured.

\section{Assay of TTSS Activity}

TTSS activity was measured as the hemolytic activity caused by TTSS of EPEC in a 96-well microplate as reported previously [7]. TTSS-expressing EPEC and erythrocytes were mixed and the hemolytic activity was measured spectrometrically. Namely, noninfectious strain EPEC $\Delta$ CesT, which was defective of the chaperon protein of Tir (translocated intimin receptor), was used in this assay. One loopful of this strain was inoculated in liquid medium $(5.0 \mathrm{ml})$ consisting of $2.5 \%$ LB medium (Funakoshi Co. Ltd., Japan) and cultured at $37^{\circ} \mathrm{C}$ for 12 hours without shaking. The seed culture $(1.0 \%)$ was transferred to M9 medium $(0.4 \%$ glucose, $0.1 \%$ casamino 
acids, $0.68 \% \mathrm{Na}_{2} \mathrm{HPO}_{4}, 0.3 \% \mathrm{KH}_{2} \mathrm{PO}_{4}, 0.05 \% \mathrm{NaCl}, 0.1 \%$ $\mathrm{NH}_{4} \mathrm{Cl}$ and $0.012 \% \mathrm{MgSO}_{4}$ ), and the main culture was incubated at $37^{\circ} \mathrm{C}$ for 4.5 hours without shaking. The culture was centrifuged at $3,000 \mathrm{rpm}$ for 15 minutes to collect the bacterial cells, which were suspended in M9 medium $(5.0 \mathrm{ml})$ and used as TTSS-expressing EPEC. In parallel, sheep blood cells (Nippon Biological Materials Center, Japan) were washed three times by suspension in saline and centrifugation at 2,500 rpm for 5 minutes. The red cells $(1.0 \mathrm{~g})$, suspended in M9 medium $(2 \mathrm{ml})$, were used as erythrocytes. Then, a test sample dissolved in M9 medium $(10 \mu \mathrm{l})$, TTSS-expressing $\operatorname{EPEC~}(45 \mu \mathrm{l})$ and erythrocytes $(45 \mu \mathrm{l})$ were added to each well of a 96 -well microplate (Corning). The microplate was centrifuged at 1,500 rpm for 10 minutes to make EPEC and erythrocytes come into contact, and was incubated at $37^{\circ} \mathrm{C}$ for 90 minutes to promote the hemolytic reaction, which was stopped by adding cooled PBS (150 $\mu \mathrm{l} /$ well). The mixture was centrifuged at $1,500 \mathrm{rpm}$ for 10 minutes, and the supernatant $(100 \mu \mathrm{l})$ was transferred to a 96-well microplate to measure the hemolytic activity by determining the absorbance at $550 \mathrm{~nm}$ with a microplate reader (Bio-Instruments Inc., U.S.A.). In control experiments (no drug) an absorbance of $0.3 \sim 0.5$ at $550 \mathrm{~nm}$ was obtained as a full hemolytic activity induced by TTSSexpressing EPEC.

\section{Assay of Antibacterial Activity}

Antimicrobial activity was measured by a paper disk method (6 mm, ADVANTEC) [15]. The culture conditions were as follows: Bacillus subtilis ATCC6633 [Davis synthetic medium $\left(0.7 \% \mathrm{~K}_{2} \mathrm{HPO}_{4}, 0.2 \% \mathrm{KH}_{2} \mathrm{PO}_{4}, 0.5 \%\right.$ sodium citrate, $0.1 \%$ ammonium sulfate, $0.2 \%$ glucose, $0.01 \% \mathrm{MgSO}_{4} \cdot 7 \mathrm{H}_{2} \mathrm{O}$ and $0.8 \%$ agar), $1.0 \%$ inoculation, $37^{\circ} \mathrm{C}, 24$ hours], Staphylococcus aureus ATCC6538P [Nutrient agar $(0.5 \%$ peptone, $0.5 \%$ meat extract and $0.8 \%$ agar), $0.2 \%$ inoculation, $37^{\circ} \mathrm{C}, 24$ hours], Micrococcus luteus ATCC9341 [Nutrient agar, $0.2 \%$ inoculation, $37^{\circ} \mathrm{C}$, 24 hours], E. coli NIHJ [Nutrient agar, $0.5 \%$ inoculation, $37^{\circ} \mathrm{C}, 24$ hours], Xanthomonas camestris KB88 [Nutrient agar, $1.0 \%$ inoculation, $37^{\circ} \mathrm{C}, 24$ hours], Aspergillus niger ATCC9642 [GY agar, $0.3 \%$ inoculation, $27^{\circ} \mathrm{C}, 48$ hours], Mucor racemosus IFO4581 [GY agar, 0.3\% inoculation, $27^{\circ} \mathrm{C}, 48$ hours], Candida albicans ATCC64548 [GY agar, $0.2 \%$ inoculation, $27^{\circ} \mathrm{C}, 24$ hours].

\section{Assay of Cytotoxic Activity}

Cytotoxic activity against Jurkat cells was measured using the colorimetric 3-(4,5-dimethylthiazo-2-yl)-2,5-diphenyltetrazolium bromide (MTT) assay in a 96-well microplate [16]. Jurkat cells growing exponentially in RPMI-1640 $\left(4 \times 10^{5}\right.$ cells $\left./ \mathrm{ml} ; \quad 50 \mu \mathrm{l}\right)$ and drugs in RPMI-1640 containing 1.0\% DMSO $(50 \mu \mathrm{l})$ were added to each well of a 96-well microplate and were then cultured at $37^{\circ} \mathrm{C}$ for 48 hours in a $5.0 \% \mathrm{CO}_{2}$ atmosphere. After incubation, MTT in phosphate buffered saline $(5.5 \mathrm{mg} / \mathrm{ml} ; 10 \mu \mathrm{l})$ was added to each well, followed by further incubation at $37^{\circ} \mathrm{C}$ for 4 hours. A $90-\mu 1$ aliquot of extraction solution $(40 \%(\mathrm{v} / \mathrm{v})$ $\mathrm{N}, \mathrm{N}$-dimethylformamide, $2.0 \%$ (v/v) $\mathrm{CH}_{3} \mathrm{COOH}, 20 \%$ $(\mathrm{w} / \mathrm{v}) \mathrm{SDS}$ and $0.03 \mathrm{~N} \mathrm{HCl})$ was added and the mixtures were shaken at room temperature for 2 hours. Cytotoxic activity was determined by measuring optical density at $550 \mathrm{~nm}$ with a microplate reader (BIO-TEK Instruments).

\section{Results}

\section{Taxonomy of the Producing Strain K01-0509}

Strain K01-0509 was isolated from a soil sample collected at Amamioshima, Kagoshima, Japan. The vegetative mycelia grew abundantly on yeast extract - malt extract agar, oatmeal agar, inorganic salt - starch agar, glycerolasparagine agar and glucose-asparagine agar, and did not show fragmentation into coccoid forms or bacillary elements. The color of vegetative mycelia was yellow to brown. The aerial mycelia grew abundantly on yeast extract-malt extract and glycerol - asparagine agar and the aerial mass color was white to gray. From observation of the scanning electron micrograph of the strain (Fig. 2), the spore chains were straight and with more than 20 spores per chain. The spores were cylindrical in shape, $0.6 \sim 0.8 \times 1.0 \sim 1.8 \mu \mathrm{m}$ in size and had a smooth surface. Whirls, sclerotic granules, sporangia and flagellate spores were not observed. The growth temperature range was $10 \sim 38^{\circ} \mathrm{C}$. D-Glucose and L-arabinose were used as the sole carbon source and D-fructose, myo-inositol, D-mannitol, melibiose, raffinose, L-rhamnose, sucrose and xylose were not used. Melanoid pigment was produced in tryptone -

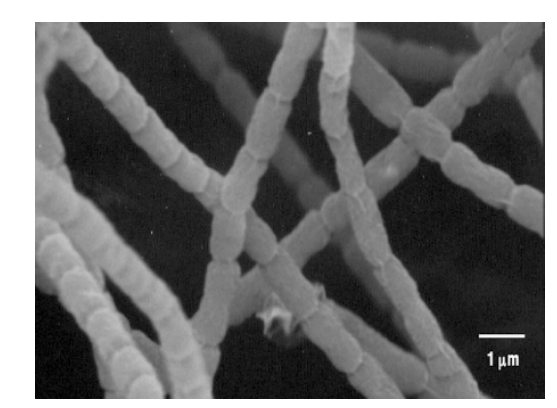

Fig. 2 Scanning electron micrograph of Streptomyces sp. K01-0509.

Bar represents $1.0 \mu \mathrm{m}$. 
yeast extract broth. No soluble pigment was found. The isomer of DAP in whole-cell hydrolysates of strain K01-0509 was determined to be an LL-form. Major menaquinones were MK-9 $\left(\mathrm{H}_{6}\right)$ and MK-9 $\left(\mathrm{H}_{8}\right)$. Based on the taxonomic properties described above, strain K01-0509 is considered to belong to the genus Streptomyces [17] and was deposited at the National Institute of Bioscience and Human-Technology, Agency of Industrial Science and Technology Japan, as FERM BP-08504.

\section{Fermentation}

Typical time courses of the fermentation for production of guadinomines $\mathrm{A}, \mathrm{B}$ and $\mathrm{D}$ in Medium $\mathrm{A}$ and for production of guadinomines $C_{1}$ and $C_{2}$ and guadinomic acid in Medium B in a 500-ml Erlenmeyer flask are shown in Fig. $3 \mathrm{a}$ and $3 \mathrm{~b}$, respectively. In Medium A the inhibitory activity of the culture broth against TTSS reached maximum levels on day $2 \sim 3$ after inoculation and then slowly decreased.

\section{Isolation}

The procedure for the isolation of guadinomines A, B and $\mathrm{D}$ is summarized in Scheme 1. The 9-day old culture broth (Medium A, 4.9 liters) was extracted with 5.0 liters of $\mathrm{Me}_{2} \mathrm{CO}$, followed by centrifugation at $3,000 \mathrm{rpm}$ to separate the mycelium and the supernatant. The supernatant was concentrated under reduced pressure to remove $\mathrm{Me}_{2} \mathrm{CO}$ and then passed through a Dowex 50W x2 $\left[\mathrm{H}^{+}\right]$column $(100$ i.d. $\times 100 \mathrm{~mm}$, Muromachi Technos Co.) previously activated. After washing with water $(900 \mathrm{ml})$, the active materials were eluted with $1.5 \mathrm{~N} \mathrm{NH} \mathrm{NH}_{4} \mathrm{OH}(900 \mathrm{ml})$, followed by neutralization by $\mathrm{HCl}$ and desalting by a micro acylizer (Asahi Chemical Co.). The whole eluate was concentrated in vacuo and lyophilized to yield a brown material $(1.1 \mathrm{~g})$. The material was dissolved in a small amount of $0.05 \mathrm{M} \mathrm{CH}_{3} \mathrm{COONH}_{4}$ buffer ( $\mathrm{pH}$ 3.7) and applied to a Toyopearl SP650-C column $(60$ i.d. $\times 110 \mathrm{~mm}$,
Tosoh Co.) previously equilibrated with $0.05 \mathrm{M}$ $\mathrm{CH}_{3} \mathrm{COONH}_{4}$ buffer ( $\mathrm{pH}$ 3.7). After washing with $0.05,0.1$ and $0.2 \mathrm{M} \mathrm{CH}_{3} \mathrm{COONH}_{4}$ buffer (pH 3.7, $900 \mathrm{ml}$ each), the active materials were eluted with $0.2,0.4$ and $0.6 \mathrm{M}$

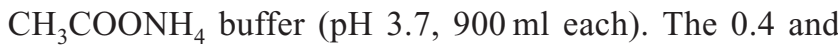
$0.6 \mathrm{M} \mathrm{CH}_{3} \mathrm{COONH}_{4}$ fractions were neutralized by $\mathrm{NH}_{4} \mathrm{OH}$. desalted by a micro acylizer and concentrated in vacuo to dryness to yield a brown material $(396 \mathrm{mg}$ ). The material was dissolved in a small amount of water and purified by HPLC on a Develosil $\mathrm{C}_{30}$ column $(20$ i.d. $\times 250 \mathrm{~mm}$, Nomura Chemical Co.) with $15 \%$ aq $\mathrm{MeOH} / 0.1 \%$ TFA at $7.0 \mathrm{ml} /$ minute detected at UV $210 \mathrm{~nm}$. The retention times of guadinomines $\mathrm{A}$ and $\mathrm{B}$ were 27 and 30 minutes, respectively (Fig. 4a). Each active fraction was concentrated in vacuo to dryness to afford guadinomine A $(3.3 \mathrm{mg})$ and guadinomine $\mathrm{B}(5.5 \mathrm{mg})$ as pale brown powders. In contrast, the $0.2 \mathrm{M} \mathrm{CH}_{3} \mathrm{COONH}_{4}$ fraction was neutralized by $\mathrm{NH}_{4} \mathrm{OH}$, desalted by a micro acylizer and concentrated in vacuo to dryness to yield a brown material (708 mg). This material was dissolved in a small amount

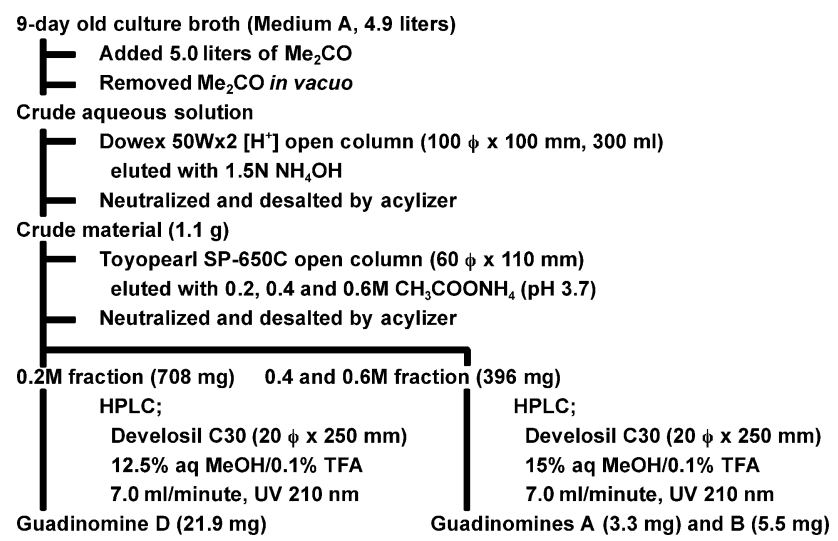

Scheme 1 Isolation procedure of guadinomines A, B and D (a)



(b)

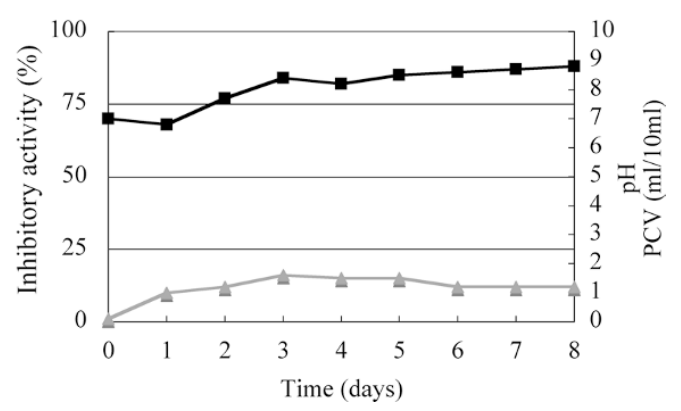

Fig. 3 Typical time course of fermentation by Streptomyces sp. K01-0509.

Strain K01-0509 was cultured in Medium A (a) or Medium B (b). The inhibitory activity against TTSS of EPEC by supernatant ( $)$ of the culture broth $(5.0 \mu \mathrm{l}), \mathrm{pH}(\mathbf{\square})$ of the culture and packed cell volume (PCV, $\mathbf{\Delta})$ were measured. 
(a)

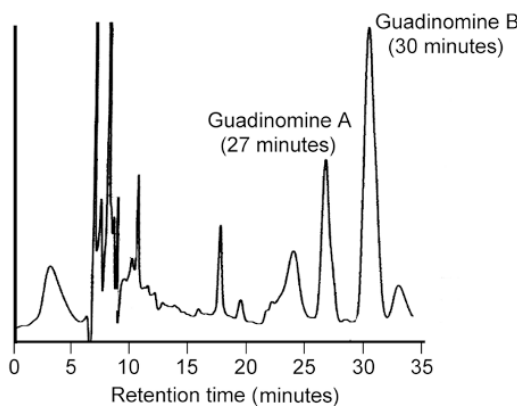

(b)

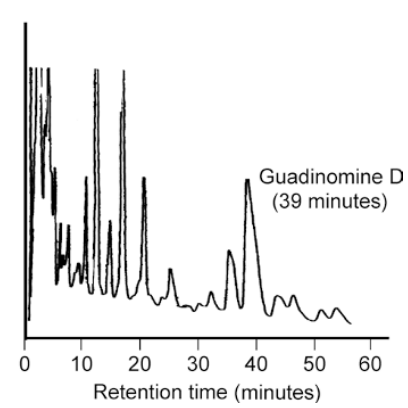

Fig. 4 Purification of (a) guadinomines $A$ and $B$ and (b) guadinomine $D$ by HPLC.

The detailed conditions of HPLC are described in the "Results".

of water and purified by HPLC on a Develosil $\mathrm{C}_{30}$ column (20 i.d. $\times 250 \mathrm{~mm}$ ) with $12.5 \% \mathrm{MeOH} / 0.1 \%$ TFA at $7.0 \mathrm{ml} /$ minute detected at UV $210 \mathrm{~nm}$. The retention time of guadinomine D was 39 minutes (Fig. 4b). The active fraction was concentrated in vacuo to dryness to afford guadinomine $\mathrm{D}(21.9 \mathrm{mg})$ as a pale brown powder.

The procedure for the isolation of guadinomines $\mathrm{C}_{1}$ and $\mathrm{C}_{2}$ guided by detection of Fearon reagent (positive for guanidine moieties) [18] is summarized in Scheme 2. The 4-day old culture broth (Medium B, 90 liters) was centrifuged at 3,000 rpm to separate the mycelium and the supernatant. The supernatant (54 liters) was passed through a column of active charcoal $(100$ i.d. $\times 80 \mathrm{~mm})$ previously activated. After washing with water $(1,500 \mathrm{ml})$, the active materials were eluted with 20 and $40 \%$ aq $\mathrm{Me}_{2} \mathrm{CO}$ $(1,500 \mathrm{ml}$ each). The whole eluate was concentrated in vacuo and lyophilized to yield a brown material $(21.5 \mathrm{~g})$. The active material was dissolved in a small amount of water and applied on a IRC-50 $\left[\mathrm{H}^{+}\right]$column (80 i.d. $\times 60 \mathrm{~mm}$, Organo Co.) previously activated. After washing with water $(900 \mathrm{ml})$, the active materials were eluted with $1.0 \mathrm{~N} \mathrm{HCl}(900 \mathrm{ml})$ followed by neutralization by $\mathrm{NaOH}$ and desalting by a micro acylizer. The whole eluate was concentrated in vacuo and lyophilized to yield a brown material $(823 \mathrm{mg})$. The material was dissolved in a small amount of water and applied to an ODS column (10 i.d. $\times 40 \mathrm{~mm}$, Senshu Scientific Co.) previously equilibrated with water. After washing with water $(10 \mathrm{ml})$, the active materials were eluted with 10 and $20 \% \mathrm{MeOH} / 0.1 \%$ TFA $(10 \mathrm{ml}$ each). The whole eluate was concentrated in vacuo to dryness to yield a brown material $(103 \mathrm{mg})$. The material was dissolved in a small amount of water and purified by HPLC on a Develosil $\mathrm{C}_{30}$ column $(20$ i.d. $\times 250 \mathrm{~mm})$ with $8.0 \% \mathrm{MeOH} / 0.1 \%$ TFA at $5.0 \mathrm{ml} /$ minute detected at UV $210 \mathrm{~nm}$. The active fraction with a retention time of 45 minutes was concentrated in vacuo to dryness to yield a

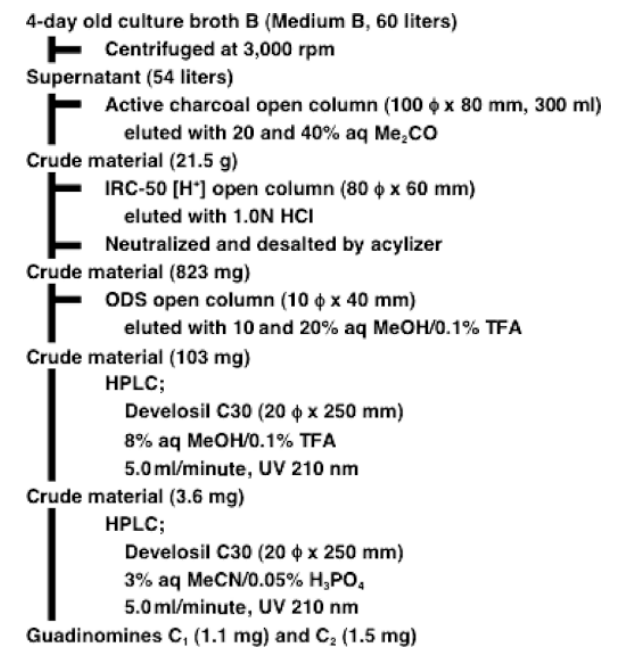

Scheme 2 Isolation procedure of guadinomines $C_{1}$ and $\mathrm{C}_{2}$

pale brown material $(3.6 \mathrm{mg})$. The material was dissolved in a small amount of water and finally purified by HPLC on a Develosil $\mathrm{C}_{30}$ column (20 i.d. $\times 250 \mathrm{~mm}$ ) with $3.0 \%$ $\mathrm{CH}_{3} \mathrm{CN} / 0.05 \% \mathrm{H}_{3} \mathrm{PO}_{4}$ at $5.0 \mathrm{ml} /$ minute detected at $\mathrm{UV}$ $210 \mathrm{~nm}$. The active fractions with retention times of 27 and 30 minutes (Fig. 5) were concentrated in vacuo to dryness to afford guadinomine $C_{1}(1.1 \mathrm{mg})$ and guadinomine $C_{2}$ $(1.5 \mathrm{mg})$ as white powders, respectively.

The procedure for the isolation of guadinomic acid guided by detection of Fearon reagent (positive for guanidine moieties) is summarized in Scheme 3. The 6-day old culture broth (Medium B, 4.2 liters) was centrifuged at $3,000 \mathrm{rpm}$ to separate the mycelium and the supernatant. The supernatant ( 3.5 liters) was passed through a cation exchange Dowex $50 \mathrm{~W} \times 2\left[\mathrm{H}^{+}\right]$column $(60$ i.d. $\times 40 \mathrm{~mm})$ previously activated. After washing with water $(500 \mathrm{ml})$, the materials were eluted with $1.5 \mathrm{~N} \mathrm{NH}_{4} \mathrm{OH}(300 \mathrm{ml})$ followed by neutralization by $\mathrm{NaOH}$ and desaltation by 


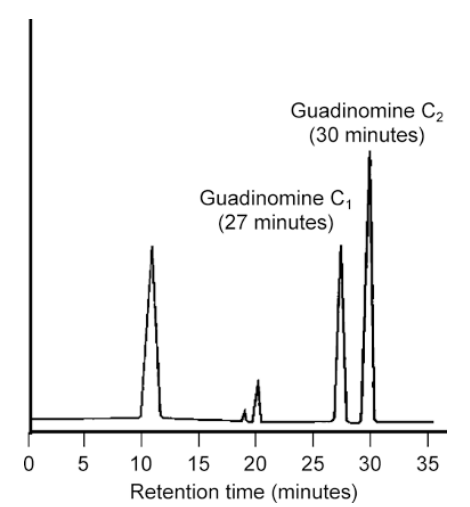

Fig. 5 Purification of guadinomines $\mathrm{C}_{1}$ and $\mathrm{C}_{2}$ by HPLC.

The detailed conditions of HPLC are described in the "Results".

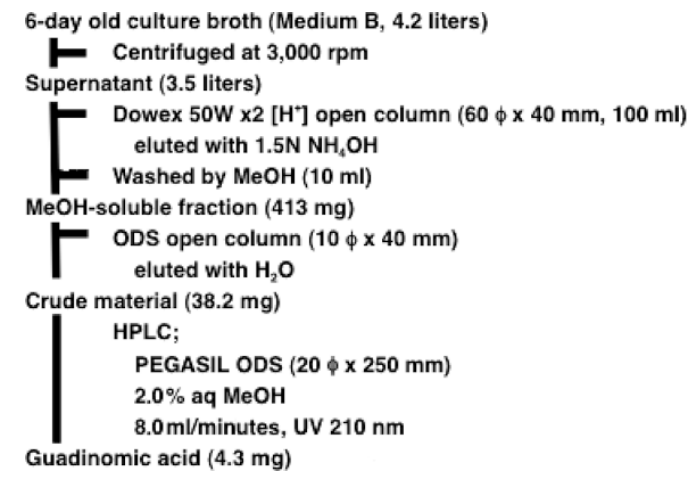

Scheme 3 Isolation procedure of guadinomic acid

micro acylizer. The whole eluate was concentrated in vacuo and lyophilized to yield a brown material $(800 \mathrm{mg})$. The material was dissolved in $10 \mathrm{ml}$ of methanol and centrifuged at 3,000 rpm. The supernatant $(413 \mathrm{mg}$ ) was applied to an ODS column $(25$ i.d. $\times 165 \mathrm{~mm})$ previously equilibrated by water. The materials were eluted with water $(200 \mathrm{ml})$. The whole eluate was concentrated in vacuo and lyophilized to yield a brown material $(38.2 \mathrm{mg})$. The material was dissolved in a small amount of water and purified by HPLC on a PEGASIL ODS column (20 i.d. $\times 250 \mathrm{~mm}$, Senshu Scientific Co.) with $2.0 \%$ aq $\mathrm{MeOH}$ at $8.0 \mathrm{ml} /$ minute detected at UV $210 \mathrm{~nm}$. The fraction with a retention time of 16 minute (Fig. 6) was collected and concentrated in vacuo to dryness to afford guadinomic acid $(4.3 \mathrm{mg})$ as a white powder.

\section{Biological Activities}

As shown in Fig. 7, guadinomines A, B and D showed dose-dependent inhibition of EPEC-induced hemolysis, suggesting that these compounds inhibited TTSS. Among

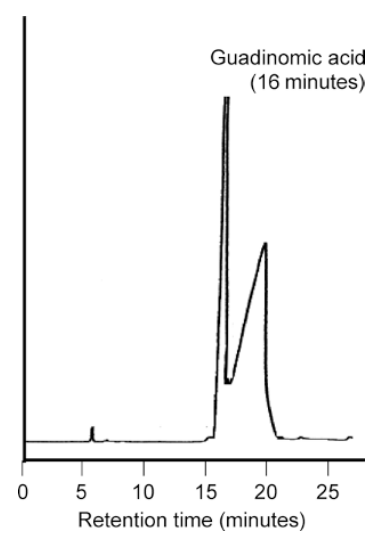

Fig. 6 Purification of guadinomic acid by HPLC.

The detailed conditions of HPLC are described in the "Results".



Fig. 7 Inhibitory activity of gudinomines against Type III secretion system of EPEC.

Guadinomine A $(\mathbf{\Delta}), B(\boldsymbol{\square})$ and $D(\bigcirc)$ and tetracycline $(\mathbf{O})$

them, guadinomine $\mathrm{B}$ was the most potent with an $\mathrm{IC}_{50}$ value of $0.007 \mu \mathrm{g} / \mathrm{ml}$, followed by guadinomine $\mathrm{A}\left(\mathrm{IC}_{50}\right.$ : $0.02 \mu \mathrm{g} / \mathrm{ml}$ ). Guadinomine D was a moderate inhibitor $\left(\mathrm{IC}_{50}: 8.5 \mu \mathrm{g} / \mathrm{ml}\right)$. However, guadinomines $\mathrm{C}_{1}$ and $\mathrm{C}_{2}$ and guadinomic acid showed no activity at $100 \mu \mathrm{g} / \mathrm{ml}$ in this assay. All guadinomines and guadinomic acid showed no antimicrobial activity against yeasts, fungi and Grampositive and Gram-negative bacteria at $10 \mu \mathrm{g} / 6 \mathrm{~mm}$ disk by the paper disk method. Guadinomine B showed cytotoxic activity against Jurkat cells with $\mathrm{IC}_{50}$ of $6.1 \mu \mathrm{g} / \mathrm{ml}$. This is 100 times higher than the inhibitory activity against EPECinduced hemolysis. Under the same condition, tetracycline inhibited EPEC-induced hemolysis with $\mathrm{IC}_{50}$ of $2.0 \mu \mathrm{g} / \mathrm{ml}$ and also showed antimicrobial activity against EPEC (inhibition zone, $19 \mathrm{~mm}$ at $10 \mu \mathrm{g} / 6 \mathrm{~mm}$ disk).

\section{Discussion}

Several compounds have been reported as TTSS inhibitors 


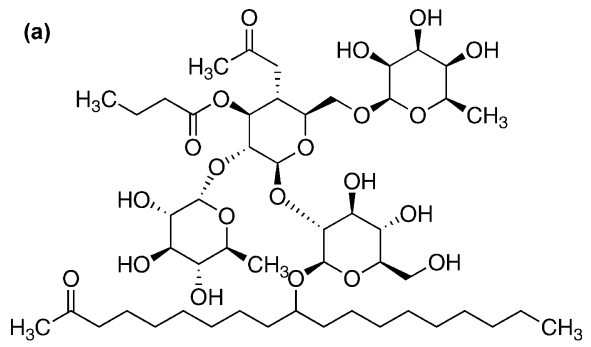

(b)<smiles>CC(=O)c1ccc(Cl)c(/N=C/c2cc(Cl)cc(Cl)c2O)c1</smiles>

(c)<smiles>O=C(N/N=C/c1cc(Br)cc(Br)c1O)c1ccc([N+](=O)[O-])cc1</smiles>

(d)

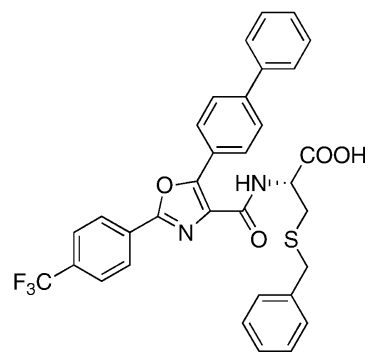

Fig. 8 Structures of (a) caminoside A, (b) synthetic TTSS inhibitor having a salicylideneaniline substructure, (c) synthetic TTSS inhibitor having an amide bond and a Shiff-base substructure and (d) synthetic TTSS inhibitor having an azole substructure.

(Fig. 8). The natural products caminosides were isolated from the marine sponge Caminus sphaeroconia in a screen system in which Esp proteins secreted from EPEC were detected by SDS-PAGE [19]. Caminoside A showed TTSS inhibition with $\mathrm{IC}_{50}$ of $38.5 \mu \mathrm{g} / \mathrm{ml}$. Lactoferrin, a highmolecular weight glycoprotein, was reported to inhibit EPEC-induced hemolysis with an $\mathrm{IC}_{50}$ value of $3.0 \mathrm{mg} / \mathrm{ml}$ because of hydrolysis of TTSS proteins [20]. Three synthetic compounds are also known to be TTSS inhibitors. The first compound having a salicylideneaniline substructure was reported to reduce the amount of Type III secretion proteins, Tir and $\mathrm{EspB}$, with $\mathrm{IC}_{50}$ of $5.1 \mu \mathrm{g} / \mathrm{ml}$ [21]. The second compound having an amide bond and a Shiff-base substructure inhibited the transcription of the TTSS-related proteins in Yersinia spp. with an $\mathrm{IC}_{50}$ of $2.2 \mu \mathrm{g} / \mathrm{ml}$ [22]. The third azole compound inhibited the transcription of the TTSS-related proteins, SopE, SipB and ExoU, in Pseudomonas murine with $\mathrm{IC}_{50}$ values of $1.9 \sim 80 \mu \mathrm{g} / \mathrm{ml}$ [23]. Thus, guadinomines are the first microbial metabolites inhibiting TTSS. Among the inhibitors listed, guadinomines $\mathrm{A}$ and $\mathrm{B}$ appear to be the most potent TTSS inhibitors reported to date with $\mathrm{IC}_{50}$ values of $0.007 \sim 0.01 \mu \mathrm{g} / \mathrm{ml}$ although the other inhibitors could not be evaluated in our assay system. Therefore, it would be useful to examine the mode of action of guadinomines in the inhibition of EPEC-induced hemolysis. TTSS inhibitors are expected to treat not only diarrhea caused by EPEC but various diseases caused by Gram-negative pathogenic bacteria.
In our assay system, guadinomines A and B showed much more potent inhibitory activity against TTSS than guadinomine $\mathrm{D}$, while guadinomines $\mathrm{C}_{1}$ and $\mathrm{C}_{2}$ showed no activity, indicating that diamino groups are important for the activity. Furthermore, guadinomic acid had no activity, indicating that the cyclic guanidine moiety alone is not sufficient for activity.

As shown in Fig. 7, tetracycline inhibited EPEC-induced hemolysis by prevention of TTSS protein synthesis and also showed anti-EPEC activity. In contrast, guadinomines markedly inhibit EPEC-induced hemolysis with no antiEPEC activity.

Acknowledgments This study was supported in part by a grant of the 21st Century COE Program and Scientific Research on Priority Areas 16073215 from the Ministry of Education, Culture, Sports, Science and Technology, Japan.

\section{References}

1. Fukuda T, Matsumoto A, Takahashi Y, Tomoda H, Ōmura S. Phenatic acids $\mathrm{A}$ and $\mathrm{B}$, new potentiators of antifungal miconazole activity produced by Streptomyces sp. K030132. J Antibiot 58: 252-259 (2005)

2. Koyama N, Nagahiro T, Yamaguchi Y, Masuma R, Tomoda $\mathrm{H}$, Ōmura S. Stemphones, novel potentiators of imipenem activity against methicillin-resitant Staphylococcus aureus, produced by Aspergillus sp. FKI-2136. J Antibiot 58: 695-703 (2005) 
3. Fukuda T, Hasegawa Y, Hagimori K, Yamaguchi Y, Masuma R, Tomoda H, Ōmura S. Tensidols, new potentiators of antifungal miconazole activity, produced by Aspergillus niger FKI-2342. J Antibiot 59: 480-485 (2006)

4. Cornelis GR, Gijsegem FV. Assembly and function of type III secretory systems. Annu Rev Microbiol 54: 735-774 (2000)

5. Anna KM, Roland N, Hanna U, Hans WW, Elofsson M. Targeting bacterial virulence: inhibitors of Type III secretion in Yersinia. Chem Biol 10: 241-249 (2003)

6. Ömura S. Antiinfective drugs into the 21 st century. Nippon Saikingaku Zasshi 54: 795-813 (1999)

7. Abe A. Jpn J Antibiot 55: 331-336 (2002)

8. Iwatsuki M, Uchida R, Yoshijima H, Ui H, Shiomi K, YongPil K, Hirose T, Sunazuka T, Abe A, Tomoda H, Ōmura S. Guadinomines, type III secretion system inhibitors, produced by Streptomyces sp. K01-0509. II. Physicochemical properties and structure elucidation. J Antibiot 61: 230-236 (2008)

9. Shiring EB, Gottlieb D. Methods for characterization of Streptomyces species. Intl J Syst Bacteriol 16: 313-340 (1966)

10. Waksman SA (Ed.). Classification, identification and description of genera and species. In The actinomycete Collins MD, Goodfellow M, Minnikin DE. Distribution of menaquinones in actinomycetes and corynebacteria. J Gen Microbiol 100: 221-230 (1977). Vol. 2. Williams and Wilkins Co. Baltimore (1961)

11. Pridham TG, Gottlieb D. The utilization of carbon compounds by some Actinomycetales as an aid for species determination. J Bacteriol 56: 107-114 (1948)

12. Becker B, Lechevalier MP, Lechevalier HA. Chemical composition of cell-wall preparation from strains of various form-genera of aerobic actinomycetes. Appl Microbiol 13: 236-243 (1965)

13. Collins MD, Goodfellow M, Minnikin DE. Distribution of menaquinones in actinomycetes and corynebacteria. J Gen Microbiol 100: 221-230 (1977)

14. Tamaoka J, Katayama-Fujiwara Y, Kuraishi H. Analysis of bacterial menaquinone mixtures by high performance liquid chromatography. J Appl Bacteriol 54: 31-36 (1983)

15. Zhang H, Tomoda H, Tabata N, Oohori M, Shinose M, Takahashi Y, Ömura S. Zelkovamycin, a new cyclic peptide antibiotic from Streptomyces sp. K96-0670 1. Production, isolation and biological properties. J Antibiot 52: 29-33 (1999)

16. Mosmann T. Rapid colorimetric assay for cellular growth and survival: application to proliferation and cytotoxicity assays. J Immunol Methods 65: 55-63 (1983)

17. Williams ST, Goodfellow M, Alderson G. Genus Streptomyces Waksman and Henrici 1943. In Bergey's Manual of Systematic Bacteriology. Volume 4. Ed., Wiliams ST et al., pp 2452-2492, Williams \& Wilkins Co. (1989)

18. List PH. Sodium pentacyanoamineferrate (II) for urea, thiourea and guanidines. Hoppe-seylers Z. Physiol Chem 305: 27 (1956)

19. Lingington RG, Robertson M, Gauthier A, Finlay BB, Soest RV, Andersen RJ. Caminoside A, an antimicrobial glycolipid isolated from the marine sponge Caminus sphaeroconia. Org Lett 23: 4089-4092 (2002)

20. Ochoa TJ, Noguera-Obenza M, Ebel F, Guzman CA, Gomez HF, Cleary TG. Lactoferrin impairs Type III secretion system function in Enteropathogenic Esherichia coli. Infect Immun 71: 5149-5155 (2003)

21. Gautheir A, Robertson ML, Lowden M, Ibarra JA, Puente JL, Finlay BB. Transcriptional inhibitor of virulence factors in enteropathogenic Esherichia coli. Antimicrob Agents Chemother 49: 4101-4109 (2005)

22. Kauppi AM, Nordfelth R, Uvell H, Wolf-Watz H, Elofsson M. Targeting bacterial virulence: inhibitors of Type III secretion in Yersinia. Chem Biol 10: 241-249 (2003)

23. Fernandez J, Abbanat D, Bush K, Hiliard J, Guan Q, Macielag M, Goldschmidt RM. In vivo efficacy of the bacterial Type III protein secretion systems (TTPS) inhibitors JNJ-1027598 and JNJ-10278385. Summary of 44th Interscience Conference Antimicrobial Agents and Chemotherapy (Oct 30 Nov 2, Washington DC) (2004) 